\title{
Why there is a need for Street Law programmes?
}

\author{
Michal Urban
}

Editorial Board member, International Journal of Public Legal Education

Winston Churchill famously noted that democracy is the worst form of government, except for all those other forms that have been tried from time to time. ${ }^{1}$ He was talking about constitutional liberal democracy in Fareed Zakaria's terms, ${ }^{2}$ combining classical liberalism with the rule of law, and he had no illusions about its weaknesses. After all, he was a witness to fall of many of those European democracies under the pressures of Nazism, fascism or communism in 1930s and 1940s. However imperfect system this kind of democracy may be, it is the system that most European countries currently have, for better or worse, and all the alternatives to it we are currently observing across the world, be it in China, Russia, Hungary or Turkey present no tempting substitute. On the contrary, these more or less illiberal democracies evoke pleasantly positive feeling towards our version of democracy, even with all its flaws.

What makes constitutional liberal democracy worth preserving? It, at least in theory, more than any other system, believes in the people and their potential to govern themselves. It has faith that citizens are in the end good, possess the power to grow

\footnotetext{
${ }^{1}$ See https://www.winstonchurchill.org/resources/quotes/the-worst-form-of-government.

${ }^{2}$ Zakaria, Fareed. The Future of Freedom: Illiberal Democracy at Home and Abroad. W.W. Norton \& Company, 2003.
} 
and learn from mistakes ${ }^{3}$ and, with sufficient systemic support, are able to handle their liberty and use it for the benefit of themselves and wider society. ${ }^{4}$ It invests in institutions that fight for rule of law and protection of human rights, especially against the ruling political power. Time and again we experience how difficult it is to put these principles in practice. As we all are experiencing, it is challenging to find reasonable consensus and refrain from using physical or psychological dominance even in families, not to mention larger diverse communities or whole societies. Moreover, the natural disadvantage of democracy, as Václav Havel put it, is that it binds the hands of those who take it seriously while allowing those who do not take it seriously to do almost anything they want. ${ }^{5}$

Despite the power of democratic institutions, be it courts, local and national parliaments, public administration or schools, no constitutional liberal democracy can be notably stronger than its citizens. Since it places so much trust into its members, it would be terribly short-sighted not to care about the depth and extent of initial and life-long education. Legally, there are clear checkpoints which we pass and on which we receive proofs of our growing maturity: an ID, right to sexual relations and marriage and right to vote to name but a few. Typically at the age of 18-21 we become, legally at least, fully-developed citizens, who possess the whole catalogue of rights

\footnotetext{
${ }^{3}$ Psychologist Carol Dweck considers our ability to grow and learn from mistakes one of the key elements of human development. See Dweck, Carol. Mindset: Changing the Way You Think to Fulfill Your Potential. Little, Brown Book Group Limited, 2017.

${ }^{4}$ Not everybody believes that people are able to "handle themselves", not to mention to govern the matters of their community together. For a thought-provoking literary capture of this view, see a chapter "The Grand Inquisitor" in Fyodor Dostoevsky's novel The brothers Karamazov. Dostoevsky, Fyodor. The brothers Karamazov: a novel in four parts with epilogue. New York: Farrar, Straus and Giroux, 2002.

${ }^{5}$ Havel, Václav. Conspirators, 1971.
} 
and duties. ${ }^{6}$ Typically, we perceive ourselves and are perceived by others as "completed", fully ready for our role, even "job" as responsible citizens.

Yes, a job, because to be that kind of a citizen democracies truly need, individuals and communities need to take responsibility and carry out duties as well as assume rights - i.e. to enter into a long-term, often difficult and only sometimes rewarding relationship with the democratic system. We generally understand that to perform any task properly, we need to prepare for it: go to school, study at home, and perhaps take exams. There is one clear exception to that, though. Although we do not expect a carpenter to master woodwork by himself, nor a pilot to leave ground without proper training, we still tend to believe that people generally naturally grow into their role of citizens.

It is clearly a myth that we develop simply organically and the growing support for populists in Europe and beyond is a clear proof of it. We all need guidance and mentors: parents educate their children, more experienced members of a sport team coach newcomers and new employees learn from more senior ones. Likewise we need to have overt citizenship education. An essential part of this, especially due to constantly rising number of laws and complexity of the world, is public legal education, aimed at increasing legal literacy. ${ }^{7}$

\footnotetext{
${ }^{6}$ There are only minor exceptions such as the right to be elected a member of an upper chamber of a parliament, which is typically higher than for the lower chamber.

${ }^{7}$ Apart from legal literacy, quality citizenship education should also increase political literacy, media literacy, information literacy and financial literacy.
} 
One ever powerful way of delivering public legal education is through Street Law.

Street Law programmes now exist around the globe, inspired by the original Georgetown Law Center initiative in Washington, D.C. in the early $1970{ }^{8}{ }^{8}$ and are one way to increase legal literacy of the public, to help them resist manipulation of different kinds and empower them in relation to the law and the legal system as its affects their everyday lives. ${ }^{9}$ One of these Street Law programmes operates at Charles University, Faculty of Law in Prague, Czech Republic, and may serve as one concrete example of a positive contribution to the cultivation of public legal literacy. ${ }^{10}$

Found in 2009, it is already a well-established programme. It originally started as a simple elective course for 15 law students but over the years it expanded into a programme of six interlinked accredited courses, which have already sent around 300 future lawyers to teach at public schools, and following activities of the Street Law alumni. Street Law activities are run by a team of about 15 alumni of the basic course, consisting of current law school students, young lawyers in practice and academics employed by the university. ${ }^{11}$ The original aim, to increase legal literacy of upper-

\footnotetext{
${ }^{8}$ Grimes, Richard, McQuoid-Mason, David, O'Brien, Ed, Zimmer, Judy. Street Law and Social Justice Education. in Bloch, Frank (ed.). The global clinical movement: educating lawyers for social justice. Oxford University Press, 2011.

${ }^{9}$ See Zariski, Archie. What is legal literacy? Available here: http://www.athabascau.ca/syllabi/lgst/docs/LGST249_sample.pdf.

${ }^{10} \mathrm{I}$ have chosen it as an example for this text not because I consider it the best in the world, but because I am the most familiar with it, since I have been running it from the very first steps. The fact that it does not belong to large, well-established programmes running for decades may serve as an advantage, since on one hand there is still much to improve, but on the other hand its activities expanded quite promptly, which might be inspiring for those who are thinking about starting Street Law programme at their universities.

${ }^{11}$ The head of the programme is a senior assistant and there is one assistant and one Ph.D. student. The fact that the programme is co-run by academic staff employed by the university is essential for continuity and sustainability of the programme. Many Street Law programmes, including a previous one at Charles University, were opened by an NGO and/or student unions, which for various reasons could not support them longer than couple of years, after which the programmes ceased to exist.
} 
secondary school students has, over the years, been expanded and now involves number of socially-challenged groups - the elderly, members of the Roma minority and prisoners. Our view is that everyone may need and certainly deserves improved legal awareness and alumni certainly benefit from the experience of working with different groups and in challenging environments. The team offers mock trials for groups of non-lawyers, publishes teaching materials and builds public databases of tested lesson plans. ${ }^{12}$ It trains school teachers, helps school classes to attend real court hearings and runs a mock trial competition among Czech secondary schools. ${ }^{13}$

In its ninth season and now running a record number of projects, the Charles University Street Law team continues to develop its work and still faces numerous challenges. The first and foremost is to keep the team large enough to manage all the work, but yet still friendly and cooperative, keeping the 'student spirit', since it runs on a voluntary basis and wants its members to feel welcome in the team. Apart from the team members, who are all doing Street Law for at least couple of years, there are also newcomers joining an extended Street Law team. ${ }^{14}$ Both these groups require attention of the head of the team and need to feel that they learn something new and contribute to Street Law aims. Similarly, the programme struggles to find balance between concentrating on working with non-lawyers and investing time and energy

\footnotetext{
${ }^{12}$ See http://streetlaw.livepreview.cz/lekce.

${ }^{13}$ For more insight into our Street Law programme, see our webpage http://www.streetlaw.eu/. Although it is mostly in Czech, there is a short English version, too.

${ }^{14}$ Apart from 15 older members, who form the Street Law team, there are some 10-15 younger members, who graduated from the basic Street Law course and are helping with follow-up activities. To recruit more Street Lawyers allows us to do more for the community, but inevitably changes the atmosphere and manageability of the team.
} 
into development of the Street Law team. Which target group is the true priority, nonlawyers, or young lawyers doing Street Law? The answer to this question differs not only among Street Law programmes, but also within teams. Both alternatives are praiseworthy, but to reach true symbioses is not as easy as one might think. Either way, as long as the Street Law programme helps increasing legal literary, it is a win/win situation for all. 